\title{
AKTIVITAS ANTIHIPERGLIKEMIA EKSTRAK AIR DAN HEKSANA DAUN PANDAN WANGI (Pandanus amaryllifolius) TERHADAP TIKUS PUTIH (Rattus novergicus)
}

\author{
Sitaresmi Yuningtyas* ${ }^{* 1}$, Siti Mariam ${ }^{1}$, Auliatun Nisa ${ }^{2}$ \\ ${ }^{1}$ Program Studi S1 Farmasi, Sekolah Tinggi Teknologi Industri dan Farmasi Bogor \\ Korespondensi: sitaresmi.yuningtyas@ gmail.com
}

\begin{abstract}
ABSTRAK
Diabetes mellitus adalah salah satu gangguan metabolisme karbohidrat yang ditandai dengan tingginya kadar glukosa darah atau hiperglikemia. Hiperglikemia merupakan keadaan dimana jumlah glukosa dalam darah melebihi batas normal. Banyak tanaman yang berpotensi sebagai penurun kadar glukosa darah, salah satunya daun pandan (Pandanus amaryllifolius). Tujuan dari penelitian adalah mengidentifikasi golongan senyawa kimia yang terkandung dalam ekstrak air dan heksana daun pandan serta menentukan aktivitas ekstrak air dan heksana daun pandan terhadap penurunan kadar glukosa darah tikus putih (Rattus novergicus) dengan hiperglikemia. Simplisia daun pandan diekstraksi dengan metode maserasi. Ekstrak kental ditentukan kandungan senyawanya dan diuji secara in vivo pada tikus hipergikemia yang diinduksi aloksan. Ekstrak air daun pandan (EADP) mengandung senyawa alkaloid, flavonoid, saponin dan tanin. Ekstrak heksana daun pandan (EHDP) mengandung senyawa alkaloid dan steroid. Pengukuran kadar glukosa darah diukur menggunakan glukometer selama 15 hari dengan interval waktu setiap 3 hari. Perlakuan kontrol negatif dengan Na-CMC 1\% meningkatkan kadar glukosa darah sebesar 137,50\%. Perlakuan kontrol positif dengan metfomin 9 mg menurunkan kadar glukosa darah sebesar 66,41\%. Perlakuan dengan pemberian EADP 300, EADP 600, EHDP 300 dan EHDP 600 dapat menurunkan kadar glukosa berturut-turut sebesar 42,38, 60,25, 26,99 dan 24,81\%. Ekstrak air dan heksana daun pandan (Pandanus amaryllifolius) dapat menurunkan kadar glukosa darah secara invivo.
\end{abstract}

Kata kunci : antihiperglikemia, glukosa darah, in vivo, maserasi, Pandanus amarylliforius.

\begin{abstract}
Diabetes mellitus is a disorder of carbohydrate metabolism characterized by high blood glucose levels, or hyperglycemia. Hyperglycemia is a condition where the amount of glucose in the blood exceeds normal limits. Many plants that have the potential as the lowering of blood glucose levels, one of which pandan leaves (Pandanus amaryllifolius). The purpose this study were to identified class of chemicals compounds contained in extracts of water and hexane pandan leaves. Beside that, this study was conducted to determine the activity extracts of water and hexane pandan leaves to decrease blood glucose levels of white rats (Rattus novergicus) with hyperglycemia. Simplicia of pandan leaves extracted by maceration method. Condensed extract contains compounds defined and tested in vivo in rats induced by alloxan. Water extract of pandan leaves (EADP) contained alkaloids, flavonoids, saponins and tannins. Hexane extract of pandan leaves (EHDP) contained alkaloids and steroids. Measurement of blood glucose levels were measured by using a glucometer for 15 days with intervals in every 3 days. Negative control treatment with Na-CMC $1 \%$ was increased in blood glucose levels to $137.50 \%$. Metfomin as positive control treatment with $9 \mathrm{mg}$ could decrease the blood glucose levels to 66.41\%. Treatment with EADP 300, EADP 600, EHDP 300 and EHDP 600 could decrease glucose levels 42.38, 60.25, 26.99 and $24.81 \%$ respectively. Therefore, water and hexane extracts of pandan leaves (Pandanus amaryllifolius) could decrease the blood glucose levels with in vivo.
\end{abstract}

Keywords: antihyperglicemia, blood glucose, in vivo, maceration, Pandanus amarylliforius. 


\section{PENDAHULUAN}

Pengobatan tradisional sebagian besar menggunakan ramuan yang berasal dari tumbuh-tumbuhan baik berupa akar, batang, biji, bunga, daun, ataupun kulit kayu. Bagianbagian dari tumbuhan tersebut mengandung senyawa metabolit sekunder yang terdiri dari empat golongan utama, yaitu steroid, flavonoid, alkaloid, dan terpenoid. Senyawa metabolit sekunder tersebut memiliki aktivitas biologis. Salah satu di antaranya dapat mengobati penyakit diabetes melitus. Diabetes melitus adalah suatu penyakit dimana kadar glukosa (gula sederhana) di dalam darah relatif tinggi atau hiperglikemia ${ }^{[16]}$.

International Diabetes Federation (IDF) menyatakan jumlah penderita diabetes melitus telah meningkat secara mengkhawatirkan. Berdasarkan hasil survey yang dilakukan oleh organisasi kesehatan dunia (WHO), Indonesia merupakan negara keempat terbesar untuk prevalensi diabetes melitus setelah India, Cina, dan Amerika Serikat. Pengobatan diabetes melitus yang digunakan dalam dunia kedokteran adalah dengan injeksi insulin dan obat hipoglikemik oral (OHO) sintetik. Obat hipoglikemik oral (OHO) tersebut disintesis dari golongan sulfonilurea, biguanid, tiazolidindion, dan meglitinida ${ }^{[5]}$. Namun penggunaan obat-obat tersebut relatif mengeluarkan biaya yang cukup mahal dan menghasilkan efek samping. Oleh karena itu, maka diperlukan obat alternatif dari berbagai jenis tumbuhan untuk mengobati penyakit dengan efek samping yang sangat kecil. Beberapa tumbuhan yang memiliki aktivitas antidiabetes, yaitu benih fenugreek (sapogenin, $50 \mathrm{mg} / \mathrm{kg}$ BB pada kelinci), daun sirih merah (flavonoid, 39,62\% pada $10000 \mathrm{ppm}$ ), biji buah alpukat $(0,980 \mathrm{~g} / \mathrm{kg}$ BB pada kelinci), dan akar tumbuhan cendana (steroid glikosida, $50 \mathrm{mg} / \mathrm{kg}$ BB pada kelinci $)^{[15]}$.

Pandan wangi (Pandanus amaryllifolius) merupakan tanaman yang sering dimanfaatkan sebagai bahan tambahan makanan, umumnya sebagai bahan pewarna hijau dan pemberi aroma. Aroma khas dari pandan wangi diduga karena adanya senyawa turunan asam amino fenilalanin yaitu 2-asetil-1-pirolin ${ }^{[6]}$. Kandungan daun pandan wangi meliputi flavonoid, alkaloid, saponin, tanin, polifenol, dan zat warna ${ }^{[1]}$. Pandan wangi dilaporkan memiliki aktivitas antidiabetik pada ekstrak air, antioksidan pada ekstrak air dan metanol, antikanker pada ekstrak etanol dan metanol, dan antibakteri pada ekstrak etanol dan etil asetat $^{[14,8,3,12]}$. Senyawa bioaktif yang terdapat dalam ekstrak air daun pandan wangi diantaranya adalah tanin, alkaloid, flavonoid, dan polifenol dan dapat menurunkan kadar glukosa darah tikus putih pada dosis $600 \mathrm{mg} / \mathrm{kg}$ $\mathrm{bb}^{[14]}$.Ekstrak etil asetat daun pandan wangi memiliki aktivitas antidiabetes secara in vitro menggunakan metode $\alpha$-glukosidase dengan nilai $\mathrm{IC}_{50} 77,57 \mathrm{ppm}^{[17]}$. Hasil-hasil penelitian tersebut mengindikasikan bahwa pemilihan pelarut yang digunakan dalam ekstraksi senyawa bioaktif dari daun pandan merupakan faktor penting yang berpengaruh pada potensi terapi.

Aktivitas antihiperglikemia dari ekstrak daun pandan ini memerlukan konfirmasi dan penelitian lanjutan untuk mengetahui kontribusi pemilihan cairan penyari pada penurunan kadar glukosa darah. Air dan heksana dalam penelitian ini diharapkan dapat menelusur keberadaan senyawa aktif yang berpotensi sebagai antihiperglikemia berdasar sifat kelarutannya pada berbagai penyari dengan polaritas berbeda. Air sebagai pelarut polar umumnya akan melarutkan senyawa golongan gula, asam amino, protein, poliglikosida, tanin, garam alkaloid, dan polifenol. Heksana dengan polaritas yang relatif paling rendah mampu melarutkan senyawa golongan alkaloid, aglikon, monoglikosida, terpenoid, dan steroid. Berdasarkah hal tersebut, penelitian ini akan menelaah kandungan senyawa bioaktif pada ekstrak air dan heksana daun pandan wangi serta mengetahui efeknya terhadap penurunan kadar glukosa darah pada tikus putih (Rattus novergicus) dengan hiperglikemia.

\section{METODE PENELITIAN}

Bahan: Tikus putih betina (Rattus novergicus) galur Sprague-Dawley, daun pandan wangi segar (Pandanus amaryllifolius Roxb.) diperoleh dari Balai Penelitian Tanaman Rempah dan Obat (BALITRO) daerah Cimanggu-Bogor, akuades, serbuk logam $\mathrm{Mg}$, $\mathrm{HCl}$, amil alkohol, $\mathrm{H}_{2} \mathrm{SO}_{4}$ p, pereaksi Dreagendorf, $\mathrm{FeCl}_{3}$, kloroform, asam asetat anhidrat, larutan $\mathrm{NaCl}$, natrium $\mathrm{CMC}$, heksana, aloksan monohidrat dan metformin (tablet@500mg). 
Alat: Kandang khusus untuk pengamatan uji antidiabetes, tempat penyimpanan simplisia, peralatan gelas, timbangan analitik, timbangan hewan, kertas saring, sarung tangan, masker, evaporator, glucometer EasyTouch, lancing device, bood lancets 28G, strip glukosa, nampan, sonde oral, jarum suntik subcutan, spuit $1 \mathrm{cc}$, spuit $3 \mathrm{cc}$, vial, alumunium foil, lumpang dan alu.

\section{Metode}

\section{Pembuatan Ekstrak Daun Pandan Wangi}

Pembuatan ekstrak dilakukan dengan cara maserasi bertingkat, daun pandan yang sudah dihaluskan dan diekstraksi dengan pelarut air dan heksana, secara bertahap dari pelarut yang paling polar hingga non-polar, yaitu air terlebih dahulu kemudian baru heksana. Simplisia daun pandan ditimbang sebanyak $100 \mathrm{~g}$ dimaserasi menggunakan pelarut air selama 3x 24 jam dengan dilakukan pergantian pelarut yang sama setiap 24 jam sesekali dilakukan pengadukan. Selanjutnya ampas dilakukan ekstraksi secara maserasi dengan pelarut heksana selama 3 hari $1 \times 24$ jam dengan dilakukan pergantian pelarut yang sama setiap 24 jam serta sesekali dilakukan pengadukan. Setelah itu dilakukan pemeriksaan organoleptik dan pengukuran $\mathrm{pH}$ pada masing-masing ekstrak. Ekstrak cair yang diperoleh dievaporasi menggunakan alat rotary evaporator sehingga diperoleh ekstrak kental. Rendemen ekstrak yang diperoleh dihitung dengan rumus sebagai berikut :

Rendemen (\%) $=\frac{\text { bobot ekstrak }(\mathrm{g})}{\text { bobot simplisia }(\mathrm{g})} \times 100 \%$

Selanjutnya ekstrak air dan heksana daun pandan dilakukan uji fitokimia dan uji antidiabetes secara in vivo.

\section{Uji Fitokimia ${ }^{[9]}$}

Ekstrak air dan heksana daun pandan wangi dilakukan uji fitokimia berupa uji kualitatif golongan senyawa alkaloid, flavonoid, saponin, tanin, steroid, dan terpenoid.

\section{Pengujian Antihiperglikemia secara In Vivo \\ Penyiapan Hewan Uji.Tikus putih betina ditimbang dan dikelompokkan menjadi 6 kelompok tiap kelompok terdiri dari 4 ekor}

tikus putih betina.Tikus diadaptasi selama seminggu dengan kondisi kandang yang disediakan. Pada hari ke-7 tikus dipuasakan selama \pm 16 jam, tetapi minum tetap diberikan. Setelah dipuasakan, darah tikus diambil dari bagian ekor untuk dicek kadar glukosa darahnya.

Induksi Hiperglikemia ${ }^{[13]}$.Semua tikus uji diinduksi aloksan dengan dosis 125 $\mathrm{mg} / \mathrm{kgBB}$ sebanyak $0,31 \mathrm{~mL}$ diberikan secara intraperitonial atau di jaringan perut. Untuk melihat efek hiperglikemia dari aloksan ditunggu selama 3 hari atau 72 jam. Setelah ditunggu 3 hari, pada hari ke-0 semua tikus diperiksa kadar glukosa darahnya menggunakan glukometer. Tikus yang digunakan adalah tikus yang sudah hiperglikemia dengan kadar glukosa tikus > $140 \mathrm{mg} / \mathrm{dL}$. Jika hasil glukosa darah tidak mendapatkan hasil signifikan, maka perlu diberikan aloksan kembali dengan volume yang sama

Pengujian Antihiperglikemia Secara In Vivo $^{[14]}$.Setelah semua kadar glukosa tikus > $140 \mathrm{mg} / \mathrm{dL}$, tiap kelompok tikus diberi perlakuan sebagai berikut :

a) Kelompok pertama kontrol negatif (-) hanya diberi Natrium CMC 1\% sebanyak 1 $\mathrm{mL}$.

b) Kelompok kedua kontrol positif (+) diberi obat pembanding metformin $9 \mathrm{mg}$ sebanyak 0,9 mL/tikus. Pemberian 2 kali sehari.

c) Kelompok ketiga diberi ekstrak air daun pandan $300 \mathrm{mg} / \mathrm{kgBB}$ (EADP 300) dengan pemberian 2 kali sehari.

d) Kelompok keempat diberi ekstrak air daun pandan $600 \mathrm{mg} / \mathrm{kgBB}$ (EADP 600) dengan pemberian 2 kali sehari.

e) Kelompok kelima diberi ekstrak heksana daun pandan $300 \mathrm{mg} / \mathrm{kgBB}$ (EHDP 300) dengan pemberian 2 kali sehari.

f) Kelompok keenam diberi ekstrak heksana daun pandan $600 \mathrm{mg} / \mathrm{kgBB}$ (EHDP 300) dengan pemberian 2 kali sehari.

g) Masing-masing tikus ditempatkan dalam kandang khusus yang tersedia, semua tikus diperlakukan dengan kondisi yang sama, pemberian makan yang sama dan tempat yang sama.

Pengecekan kadar glukosa darah dilakukan dengan interval setiap 3 hari selama 15 hari (hari ke-0, 3, 6, 9, 12 dan 15). Pengukuran glukosa darah diukur menggunakan glukometer. Persentase 
perubahan glukosa darah (\%) dihitung dengan rumus :

$$
\frac{\overline{\mathrm{x} K G D h a r i k e 15}-\overline{\mathrm{x} K G D h a r i k e 0}}{\overline{\mathrm{x} K G D h a r i k e 0}} \times 100 \%
$$

Keterangan :

$$
\text { KGD }=\text { Kadar Glukosa Darah }
$$

\section{Analisis Data}

Data perubahan kadar glukosa yang diperoleh dari setiap kelompok perlakuan dianalisis menggunakan analisis deskriptif dengan persentase perubahan antar perlakuan. Sehingga diketahui peningkatan dan penurunan kadar glukosa darah terhadap tikus putih.

\section{HASIL DAN PEMBAHASAN}

\section{Ekstraksi Daun Pandan Wangi}

Metode yang digunakan dalam penelitian ini yaitu metode maserasi menggunakan pelarut air dan heksana. Pemilihan pelarut dengan menggunakan air sebagai pelarut polar umumnya berdasarkan ketertarikan senyawa yang terkandung dalam pandan yang termasuk senyawa golongan flavonoid, garam alkaloid, tanin, polifenol, poliglikosida. Heksana dengan polaritas rendah mampu melarutkan senyawa yang bersifat non-polar seperti yang termasuk senyawa golongan alkaloid, terpenoid, steroid, monoglikosida ${ }^{[9]}$.

Hasil ekstraksi air daun pandan wangi yang diperoleh berupa ekstrak cair berwarna hijau kuning kecoklatan, karena dalam daun pandan terdapat zat hijau daun, yaitu klorofil dengan hasil pengukuran $\mathrm{pH}$, yaitu 5,76 dan hasil ekstraksi heksana daun pandan wangi diperoleh ekstrak cair berwarna kuning karena sudah tidak ada zat klorofil karena klorofil hanya terlarut dalam pelarut polar dengan hasil pengukuran $\mathrm{pH}$, yaitu 5,72. Hal ini menunjukkan ekstrak bersifat asam disebabkan karena adanya senyawa asam yang terdapat pada daun pandan wangi . Berdasarkan literatur daun pandan mengandung senyawa asam linoleat dan asam stearat ${ }^{[3]}$. Ekstrak air memiliki rendemen yang lebih besar dibandingkan dengan ekstrak heksana dengan nilai rendemen ekstrak air, yaitu 13,49\% dan ekstrak heksana 1,88\%. Ekstraksi air menghasilkan rendemen yang lebih besar, karena senyawa polar lebih terkonsentrasi pada ekstrak tersebut. Tingginya rendemen ekstrak pada pelarut polar dikarenakan makromolekul gula sederhana seperti monosakarida dan oligosakarida ikut terlarut dalam pelarut polar namun tidak larut dalam pelarut non-polar.

\section{Uji Fitokimia}

Hasil uji fitokimia secara kualitatif menunjukkan bahwa ekstrak air daun pandan wangi mengandung senyawa alkaloid, flavonoid, tanin dan saponin. Ekstrak heksana mengandung senyawa alkaloid dan steroid. Air sebagai pelarut polar umumnya akan melarutkan senyawa golongan gula, asam amino, protein, poliglikosida, tanin, garam alkaloid, dan polifenol. Heksana dengan polaritas yang relatif paling rendah mampu melarutkan senyawa golongan alkaloid, aglikon, monoglikosida, terpenoid, dan steroid $^{[9]}$.

\section{Pengujian Antihiperglikemia secara In Vivo}

Berdasarkan Tabel 1, terjadi perubahan kadar glukosa setelah perlakuan 15 hari. Hasil ragam analisis pada hari ke -0 , semua perlakuan menunjukkan perbedaan terhadap tikus kelompok kontrol negatif yang tidak diberi terapi apapun yang mengalami peningkatan kadar glukosa secara terus menerus. Kadar glukosa darah kontrol negatif pada hari ke -0 sebesar $182 \mathrm{mg} / \mathrm{dL}$ dan kadar glukosa pada hari ke -15 sebesar $432,25 \mathrm{mg} / \mathrm{dL}$, sehingga terjadi peningkatan kadar glukosa darah sebesar $137,50 \%$. Sel - sel $\beta$ pankreas yang rusak oleh aloksan menyebabkan sel $\beta$ pankreas tidak dapat mensenkresikan insulin sehingga terjadinya peningkatan kadar glukosa darah. Oleh sebab itu, perlakuan kontrol negatif ini memiliki aktivitas meningkatkan kadar glukosa darah tikus, sehingga Na-CMC $1 \%$ tidak berpotensi dalam menurunkan kadar glukosa darah.

Tabel 1.Hasil Persentase Perubahan Kadar Glukosa Darah Selama Lima Belas Hari Perlakuan

\section{\begin{tabular}{|l|l|}
\hline Perlakuan & Kadar Glukosa Darah (mg/dL) \\
\hline
\end{tabular}}




\begin{tabular}{|l|c|c|c|}
\hline & $\begin{array}{c}\text { Hari } \\
\text { ke -0 }\end{array}$ & $\begin{array}{c}\text { Hari } \\
\text { ke -15 }\end{array}$ & $\begin{array}{c}\text { Persen } \\
\text { Perubahan } \\
(\%)\end{array}$ \\
\hline $\begin{array}{l}\text { Kontrol } \\
\text { Negatif }\end{array}$ & 182,00 & 432,25 & 137,50 \\
\hline $\begin{array}{l}\text { Kontrol } \\
\text { Positif }\end{array}$ & 297,75 & 100,00 & $-66,41$ \\
\hline EADP 300 & 508,50 & 293,00 & $-42,38$ \\
\hline EADP 600 & 454,75 & 180,75 & $-60,25$ \\
\hline EHDP 300 & 440,00 & 321,25 & $-26,99$ \\
\hline EHDP 600 & 388,00 & 291,75 & $-24,81$ \\
\hline Keterangan : & & & \\
\hline
\end{tabular}

Keterangan :

- Apabila persen perubahan bernilai positif (+), artinya terjadi peningkatan kadar glukosa darah

- Apabila persen perubahan bernilai negatif (-), artinya terjadi penurunan kadar glukosa darah

Perlakuan kontrol positif pada Tabel 1, memiliki kadar glukosa darah pada hari ke -0 sebesar 297,75 mg/dL dan hari ke -15 sebesar $100 \mathrm{mg} / \mathrm{dL}$. Persentase penurunan kadar glukosa darah pada tikus yaitu sebesar $66,41 \%$. Hal ini disebabkan karena mekanisme metformin yang dapat dalam menurunkan kadar glukosa darah diantaranya menstimulasi glikolisis langsung pada jaringan perifer dengan peningkatan pengeluaran glukosa darah, meningkatkan pengikatan insulin pada reseptor insulin, memperlambat absorbsi glukosa dari darah dan kerja metformin tidak bergantung pada fungsi sel $\beta$ pankreas ${ }^{[11]}$.

Perlakuan pada terapi EADP 600 memiliki kadar glukosa darah pada hari ke -0 sebesar $454,75 \mathrm{mg} / \mathrm{dL}$ dan hari ke -15 sebesar 180,75 $\mathrm{mg} / \mathrm{dL}$. Kadar glukosa darah pada tikus memiliki nilai persentase yang hampir sama dengan kontrol positif yaitu sebesar $60,25 \%$. Kadar glukosa darah pada perlakuan kelompok EADP 300 pada hari ke -0 sebesar $508,50 \mathrm{mg} / \mathrm{dL}$ dan hari ke -15 sebesar 293,00 $\mathrm{mg} / \mathrm{dL}$. Persentase penurunan kadar glukosa darah pada tikus yaitu sebesar 42,38\%. Aktivitas penurunan kadar glukosa darah pada EADP 300 lebih rendah daripada EADP 600. Hal ini disebabkan karena dosis yang diberikan lebih rendah sehingga kurang efektif dalam penurunan kadar glukosa darah.

Perlakuan pada terapi EHDP 600 memiliki kadar glukosa darah pada hari ke -0 sebesar $388,00 \mathrm{mg} / \mathrm{dL}$ dan hari ke -15 sebesar 291,75 $\mathrm{mg} / \mathrm{dL}$. Persentase penurunan kadar glukosa darah pada tikus yaitu sebesar $24,81 \%$. Kadar glukosa darah pada perlakuan kelompok EHDP 300 pada hari ke -0 sebesar $440,00 \mathrm{mg} / \mathrm{dL}$ dan hari ke -15 sebesar $321,25 \mathrm{mg} / \mathrm{dL}$. Persentase penurunan kadar glukosa darah pada tikus yaitu sebesar 26,99\%. Aktivitas penurunan kadar glukosa darah pada EHDP 300 lebih tinggi dibandingkan EHDP 600. Hal ini disebabkan karena perbedaan respon yang dihasilkan dari masing-masing individu hewan percobaan terhadap kerusakan sel $\beta$ pankreas yang oleh zat penginduksi diabetes. Namun pada perlakuan EHDP tetap dapat menurunkan kadar glukosa darah disebabkan karena adanya senyawa aktif yang terdapat pada ekstrak ini, yaitu alkaloid dan steroid.

Kadar optimum dalam menurunkan kadar glukosa darah tikus putih pada EADP dengan dosis $600 \mathrm{mg} / \mathrm{kgBB}$ selama 4 minggu sebesar $25,72 \%^{[14]}$. Pada penelitian ini terapi dengan EADP $600 \mathrm{mg} / \mathrm{kgBB}$ pada tikus dapat menurunkan kadar glukosa darah sebanyak 60,25\% selama 15 hari. Hal ini disebabkan oleh kandungan senyawa aktif pada EADP diantaranya alkaloid, flavonoid, saponin, dan tanin.

Hasil EADP mengandung senyawa alkaloid, flavonoid, saponin dan tanin. Hasil EHDP mengandung senyawa alkaloid dan steroid. Senyawa-senyawa aktif ini dapat menurunkan kadar glukosa darah. Alkaloid bekerja dengan menstimulasi hipotalamus untuk meningkatkan sekresi Growth Hormone Releasing Hormone (GHRH), sehingga sekresi Growth Hormone(GH) pada hipofisis meningkat. Kadar GH yang tinggi akan menstimulasi hati untuk mensekresikan Insulinlike Growth Factor-1 (IGF-1). IGF-1 mempunyai efek dalam menginduksi hipoglikemia dan menurunkan glukoneogenesis sehingga kadar glukosa darah dan kebutuhan insulin menurun. IGF-1 melalui negative feed back system akan menormalkan kembali kadar $\mathrm{GH}^{[10]}$. Flavonoid memiliki aktivitas hipoglikemik atau penurun kadar glukosa darah dengan menghambat enzim-enzim penting yang berperan dalam pemecahan karbohidrat menjadi monodakarida yang dapat diserap oleh usus, yaitu enzim alfa amilase dan enzim alfa glukosidase. Penghambatan pada kedua enzim tersebut berakibat terganggunya proses pemecahan karbohidrat menjadi monosakarida sehingga tidak dapat diserap oleh usus. Dengan demikian, kadar glukosa darah tidak meningkat setelah mengkonsumsi makanan yang mengandung glukosa ${ }^{[2]}$. Tanin berfungsi sebagai astringent (pengkhelat) yang dapat menciutkan membran epitel usus halus sehingga mengurangi penyerapan sari makanan sehingga menghambat asupan gula dan laju peningkatan glukosa darah tidak terlalu tinggi $^{[4]}$. Senyawa saponin juga diketahui dapat 
menurunkan kadar glukosa darah. Berdasarkan hasil pemeriksaan hispatologi, diketahui bahwa saponin dapat meregenerasi pankreas yang menyebabkan adanya peningkatan jumlah sel $\beta$ pankreas dan pulau-pulau Langerhans sehingga sekresi insulin akan mengalami peningkatan. Peningkatan sekresi insulin tersebut akan membantu menurunkan kadar glukosa darah. Regenerasi sel $\beta$ pankreas itu terjadi karena adanya sel quiscent pada pankreas yang memiliki kemampuan bergenerasi. Steroid merupakan bagian struktur aglikon dari saponin, dimana steroid ini dapat menstimulasi kerjanya insulin dari pankreas sehingga dapat menurunkan kadar glukosa darah ${ }^{[7]}$.

\section{SIMPULAN}

Ekstrak air dan heksana daun pandan wangi memiliki aktivitas dalam penurunan kadar glukosa darah pada tikus. Rendemen EADP sebesar 13,49\% dan EHDP sebesar $1,88 \%$. Senyawa aktif yang terdapat pada ekstrak air daun pandan mengandung alkaloid, flavonoid, saponin, dan tanin sedangkan ekstrak heksana daun pandan mengandung alkaloid dan steroid. Perlakuan kontrol negatif dengan NaCMC 1\% meningkatkan kadar glukosa darah sebesar $137,50 \%$. Perlakuan kontrol positif dengan metfomin $9 \mathrm{mg}$ sebesar 66,41\%. Perlakuan dengan pemberian EADP 300, EADP 600, EHDP 300 dan EHDP 600 dapat menurunkan kadar glukosa berturut-turut sebesar 42,38, 60,25, 26, 99 dan 24,81\%.

\section{SARAN}

Penelitian selanjutnya perlu dilakukan identifikasi golongan flavonoid yang dapat menurunkan kadar glukosa darah menggunakan kromatografi lapis tipis sehingga dapat diketahui senyawa yang lebih spesifik dalam penurunan kadar glukosa darah menggunakan daun pandan serta dapat dilakukan pengujian in vivo menggunakan jus pandan.

\section{DAFTAR PUSTAKA}

[1]. Arisandi, Andriani. 2008. Khasiat Berbagai Tanaman Untuk Pengobatan. Jakarta: Eksa Media.

[2]. Brahmachari, G. 2011. Bio-flavonoids with promising antidiabetic potentials: A critical survey. Opportunity, Challenge and Scope of Natural Products in Medicinal Chemistry: 187-212.

[3]. Chong, H. Z., Yeap, S. K., Rahmat, A., Akim, A. M., Alitheen, N. B., Othman, F., Gwendolin-Ee, C. L. 2012. In Vitro Evaluation of Pandanus amaryllifolius Ethanol extract for Induction of Cell Death on Non-Hormonal Dependent Human Breast Adenocarcinoma MDAMB-231 cell via apoptosis. BMC Complementaray \& Alternative Medicine 12:134.

[4]. Daliamartha, S. 2005. Ramuan Tradisional untuk Pengobatan Diabetes Mellitus. Bogor: Penebar Swadaya.

[5]. Dallimunthe. 2004. Diabetes Melitus: Peranan Insulin, Reseptor Insulin, dan Penanganannya. Medan: USU.

[6]. Faras, A.F., Wadkar, S.S., Ghosh, J.S. 2014. Effect of Leaf Extract of Pandanus amaryllifolius Roxb on Growth of Escherichia coli and Micrococcus (Staphylococcus aureus). International Food Research Journal 21(1):421-423.

[7]. Firdous, M., Koneri, R., Sarvaraidu, C.H., Shubhapriya, K.H. 2009. NIDDM Antidiabetic Activity of Saponins of Momordica Cymbalaria In Streptozotocin-Nicotinamide NiDDM Nice. Journal of Clinical and Diagnosis Research 3: 1460-1465.

[8]. Ghasemzadeh, A., Jaafar, H. Z. E. 2013. Profiling of Phenolis Compounds and Their Antioxidant and Anticancer Activities in Pandan (Pandanus amaryllifolius Roxb.) Extract from Different Locations of Malaysia. BMC Complementary and Alternative Medicine 13:341.

[9]. Harborne, J.B. 1987. Metode Fitokimia, Penuntun Cara Modern Menganalisis Tumbuhan. Bandung: Penerbit ITB.

[10]. Ho, E., Bray, T.M. 1999. Antioxidants, NFKB Activation and Diabetogenesis. Proc Soc Exp Biol Med. Dec: 222(3): 20513. 
[11]. Katzung, B.G. 2007. Pancreatic Hormones and Antidiabetic Drugs. In: Basic and Clinical Pharmacology10 ${ }^{\text {th }}$ Ed 41: 683-705.

[12]. Muhardi, Suharyono, A.S., Susilawati. 2007. Aktivitas Antibakteri Daun Salam (Syzygium polyanta) dan Daun Pandan Wangi (Pandanus amaryllifolius). Jurnal Teknol dan Pangan (18) : 17-24.

[13]. Mumuh. 2000. Efektivitas penggunaan Aloksan terhadap Hewan Uji Tikus dan Cara Penyuntikan Aloksan yang Efektif. Bandung: Universitas Padjadjaran.

[14]. Prameswari, O. M., Widjanarko, S. B. 2014. Uji Efek Ekstrak Air Daun Pandan Wangi Terhadap Penurunan Kadar Glukosa Darah Dan Histopatologi Tikus Diabetes Mellitus. Jurnal Pangan dan Agroindustri Vol.2 (2): 16-2.

[15]. Saleh, C. 2007. Isolasi dan Penentuan Struktur Senyawa Steroid dari Akar Tumbuhan Cendana (Santalum album Linn).[Disertasi]. Medan: Universitas Sumatera Utara

[16]. Soegondo, S. 2005. Diagnosis dan Klasifikasi Diabetes Melitus Terkini dalam Penatalaksanaan Diabetes Melitus Terpadu. Jakarta: UI Press.

[17]. Sukandar, D., Sumarlin, L.O, Zahroh, H., Amelia, E.R. 2012. Uji Aktivitas Antidiabetes Fraksi Etil Asetat Daun Pandan Wangi ( $P$. amaryllifolius Roxb) dengan Metode $\alpha$-Glukosidase. Valensi Vol. 2 (5): 534-540. 